Paper ini adalah versi Bahasa Indonesia dari paper kami yang berjudul "Water Resources in Pari Cay, Kepulauan Seribu, Jakarta, Indonesia". Paper ini kami submit ke "The Second International Conference on Environmental Resources Management in Global Region". Konferensi insyaAllah diselenggarakan di Fakultas Geografi UGM tanggal 22 - 23 Oktober 2018.

\title{
Sumberdaya Air di Pulau Koral Pari, Kepulauan Seribu, Jakarta, Indonesia
}

\author{
Ahmad Cahyadi ${ }^{1}$, Fauzi Ramadhoan ${ }^{2}$, Muhammad Havis Damar Sasongko ${ }^{3}$ \\ ${ }^{1}$ Environmental Geography Department, Faculty of Geography, Universitas Gadjah \\ Mada \\ ${ }^{2,3}$ Planning and Management of Coastal Area and Watershed, Faculty of Geography, \\ Universitas Gadjah Mada \\ ahmadcahyadi@geo.ugm.ac.id
}

\begin{abstract}
Pulau Koral Pari merupakan pulau terbesar yang terdapat di Gugusan Kepulauan Seribu. Pertumbuhan penduduk dan perkembangan pariwisata di Pulau Koral Pari beberapa tahun ini menimbulkan tantangan baru dalam pengelolaannya, salah satunya terkait dengan sumberdaya air. Penelitian ini bertujuan untuk menganalisis kondisi sumberdaya air di Pulau Koral Pari. Cakupan penelitian meliputi analisis sumberdaya air meteorologis dan airtanah. Analisis sumberdaya air meteorologis dilakukan dengan menggunakan metode ThorntwaiteMather, sedangkan analisis sumberdaya airtanah dilakukan dengan menganalisis kualiltas airtanah menghitung kuantitas airtanah statis. Hasil analisis menunjukkan bahwa secara meteorologis deficit terjadi pada Bulan Juli dan Agustus. Kualitas airtanah di lokasi kajian menunjukkan adanya daya hantar lintrik yang dominan tinggi, pengayaan magnesium dan klorida sebagai akibat dari pengaruh intrusi air laut. Selain itu, jumlah airtanah di Pulau Pari tergolong cukup banyak dan memiliki kondisi yang lebih baik dibandingkan pulau-pulau koral lain di Gugusan Kepulauan Seribu.
\end{abstract}

\section{Introduction}

Kepulauan Seribu merupakan gugusan kepulauan yang terletak di Daerah Khusus Ibukota Jakarta, Indonesia. Gugusan kepulauan ini terletak di Laut Jawa, tepatnya di utara Teluk Jakarta dan Provinsi Banten. Secara astronimis, Gugusan Kepulauan Seribu terletak antara 106 $19^{\prime} 30^{\prime \prime}$ 106 $44^{\prime} 50^{\prime \prime}$ Bujur Timur (BT) dan antara $5^{\circ} 10^{\prime} 00^{\prime \prime}-5^{\circ} 59^{\prime} 30^{\prime \prime}$ Lintang Selatan (LS), sedangkan Pulau Koral Pari terletak antara 106 36'15" - 106 37'34" dan BT 5 $5^{\circ} 44^{\prime} 14^{\prime \prime}$ - 5 $5^{\circ} 45^{\prime} 09^{\prime \prime}$ atau dalam proyeksi Universal Transverse Mercator (UTM) terletak pada Zona 48M antara 678447 - 678935 Meter Timur (MT) dan antara 9364324 - 9365041 MT.

Gugusan kepulauan Seribu terdiri dari 110 pulau koral [1]. Keseluruhan pulau koral di gugusan kepulauan ini merupakan patch reef dengan material permukaan berupa rombakan bioklastik $[2,3]$. Berdasarkan luasnya, semua pulau koral di Gugusan Kepulauan Seribu masuk dalam kategori pulau sangat kecil, yaitu pulau dengan luas tidak lebih dari $100 \mathrm{~km}^{2}$ dan atau memiliki lebar kurang dari 3 $\mathrm{km}[4,5]$.

Salah satu pulau koral di Gugusan Kepulauan Seribu adalah Pulau Koral Pari. Pulau ini merupakan pulau koral dengan ukuran terbesar di Kepulauan Seribu, yakni 41,32 hektar. Secara astronomis Pulau ini terletak pada $5^{0} 50^{\prime} 20^{\prime \prime}-5^{0} 50^{\prime} 25^{\prime \prime}$ LS dan $106^{0} 34^{\prime} 30^{\prime \prime}-106^{0} 38^{\prime} 20^{\prime \prime} \mathrm{BT}$, sedangkan secara administrative terletak di Kelurahan Pulau Koral Pari, Kecamatan Pulau Seribu Selatan, Kabupaten Kepulauan Seribu, Daerah Khusus Ibukota Jakarta. 
Paper ini adalah versi Bahasa Indonesia dari paper kami yang berjudul "Water Resources in Pari Cay, Kepulauan Seribu, Jakarta, Indonesia". Paper ini kami submit ke "The Second International Conference on Environmental Resources Management in Global Region". Konferensi insyaAllah diselenggarakan di Fakultas Geografi UGM tanggal 22 - 23 Oktober 2018.

Pulau Koral Pari merupakan pulau yang awalnya hanya digunakan sunggah bagi nelayan saat mencari ikan. Namun perkembangannya, Pulau Koral Pari kemudian menjadi lokasi permukiman. Rencana tata ruang wilayah DKI Jakarta pun merencanakan pulau ini menjadi kawasan permukiman. Saat ini jumlah penduduk di Pulau Pari adalah sejumlah 930 jiwa atau 265 Kepala Keluarga. Jumlah ini terus mengalami kenaikan dari tahun ke tahun. Selain itu, perkembangan pariwisata yang pesat menyebabkan wilayah ini jumlah kebutuhan akan sumberdaya termasuk sumberdaya air semakin meningkat [6].

Seperti pulau koral dengan ukuran sangat kecil lainnya, Pulau Koral Pari menghadapi permasalahan yang terkait dengan sumberdaya air [7]. Curah hujan yang relatif kecil, imbuhan airtanah yang kecil, evapotranspirasi yang tinggi, tidak adanya imbuhan airtanah dari wilayah lain, dan pengaruh intrusi air laut merupakan faktor yang menyebabkan terbatasnya jumlah sumberdaya air di pulau koral sangat kecil $[8,9,10]$. Material rombakan bioklastik yang memiliki permeabilitas yang tinggi juga menyebabkan airtanah di pulau koral memiliki dinamika yang tinggi dalam hal kualitas airtanah $[11,12]$. Perubahan kualitas airtanah sangat dipengaruhi oleh pencemaran oleh limbah dan sampah rumah tangga serta intrusi air laut.

Penelitian ini bertujuan untuk menganalisis kondisi sumberdaya air di Pulau Koral Pari. Kondisi sumberdaya air yang dimaksud terdiri dari kondisi sumberdaya air meteorologis yang dicerminkan dari kondisi hujan dan suhu (evapotranspirasi) serta kuantitas dan kualitas airtanah. Penelitian ini diharapkan dapat memberikan sumbangsih berupa gambara kondisi sumberdaya air di Pulau Koral Pari, sehingga dapat dimanfaatkan dalam perencanaan pembangunan dan pengembangan Pulau Koral Pari di masa mendatang.

\section{Methodology}

\subsection{Analisis Sumberdaya Air Meteorologis}

Data yang digunakan dalam analisis sumberdaya air meteorologis terdiri dari data hujan, data suhu, data lokasi astronomis lokasi penelitian, data tekstur tanah dan data penutup/penggunaan lahan. Data hujan dan suhu diperoleh dari stasiun klimatologi milik Lembaga Ilmu Pengetahuan Indonesia (LIPI) di Pulau Koral Pari [13] (Tabel 1). Letak astronomis lokasi penelitian diperoleh dengan pengeplotan lokasi dengan global positioning system receiver. Data tanah dianalisis dengan komparator tekstur pasir dan data penutup/penggunaan lahan dianalisis berdasarkan pada citra satelit resolusi tinggi (GeoEyes). Analisis kondisi sumberdaya air meteorologis dalam penelitian ini dilakukan dengan metode Thorntwaite-Mather.

Tabel 1. Data Hujan, Suhu dan Evapotranspirasi di Pulau Koral Pari.

\begin{tabular}{|c|c|c|c|c|c|c|}
\hline \multirow[t]{2}{*}{ No. } & \multirow[t]{2}{*}{ Month } & \multicolumn{3}{|c|}{ Rainfall (mm) } & \multirow{2}{*}{$\begin{array}{c}\text { Potencial } \\
\text { Evapotranspiration (Ep) }\end{array}$} & \multirow{2}{*}{$\begin{array}{c}\text { Actual } \\
\text { Evapotranspiration } \\
\text { (Ea) }\end{array}$} \\
\hline & & Minimum & Average & Maximum & & \\
\hline 1 & January & 259 & 424 & 747 & 54 & 54 \\
\hline 2 & February & 35 & 309 & 723 & 50 & 50 \\
\hline 3 & March & 58 & 149 & 388 & 57 & 57 \\
\hline 4 & April & 0 & 132 & 340 & 56 & 56 \\
\hline 5 & May & 23 & 98 & 205 & 58 & 58 \\
\hline 6 & June & 24 & 88 & 216 & 53 & 53 \\
\hline 7 & July & 0 & 81 & 293 & 57 & 57 \\
\hline 8 & August & 0 & 46 & 162 & 57 & 52 \\
\hline 9 & September & 0 & 41 & 141 & 58 & 44 \\
\hline 10 & October & 0 & 68 & 250 & 60 & 60 \\
\hline 11 & November & 0 & 104 & 300 & 57 & 57 \\
\hline 12 & December & 0 & 243 & 726 & 59 & 59 \\
\hline
\end{tabular}

Sumber: Stasiun meteorologi Pulau Koral Pari [13] dan hasil analisis data. 
Paper ini adalah versi Bahasa Indonesia dari paper kami yang berjudul "Water Resources in Pari Cay, Kepulauan Seribu, Jakarta, Indonesia". Paper ini kami submit ke "The Second International Conference on Environmental Resources Management in Global Region". Konferensi insyaAllah diselenggarakan di Fakultas Geografi UGM tanggal 22 - 23 Oktober 2018.

\subsection{Analisis Sumberdaya Airtanah}

Analisis sumberdaya airtanah terdiri atas analisis kualitas airtanah dan kuantitas airtanah. Sampel airtanah untuk analisis kualitas air diambil berdasarkan grid imaginer dengan ukuran $300 \mathrm{~m} \mathrm{x}$ $100 \mathrm{~m}$ (Gambar 1). Pengambilan sampel dilakukan pada sumur yang terdapat pada masing-masing grid, sedangkan beberapa grid yang tidak terdapat sumur dilakukan pengeboran sampai dengan airtanah untuk diambil sampelnya. Parameter yang dianalisis terdiri dari natrium, kalium, kalsium, magnesium, klorida, sulfat, bikarbonat, nitrit, nitrat, BOD, COD, dan daya hantar listrik. Analisis kualitas air dilakukan dengan membandingkan hasil analisis laboratorium dan pengukuran lapangan dengan baku mutu kualitas air untuk air minum.

Data yang digunakan untuk analisis kuantitas airtanah adalah data kondisi akuifer, kualitas airtanah dan konduktivitas hidarulik material $[14,15]$. Data terkait dengan kondisi akuifer yang digunakan untuk mengetahui volume potensial akuifer yang dapat menyimpan airtanah diperoleh dari penelitian sebelum yang dilakukan di lokasi penelitian. Data kualitas air (dalam hal ini salinitas airtanah) digunakan untuk menentukan ketebalan airtanah tawar di Pulau Koral Pari. Penentuan ketebalan airtanah tawar dilakukan dengan menggunakan metode Ghyben-Herzberg [16]. Penentuan nilai konduktivitas hidraulik dari akuifer di Pulau Koral Pari ditentukan dengan metode inver auger hole pada muka airtanah yang memiliki kedalaman dalam (lebih dari 2 meter) dan metode auger hole untuk muka airtanah yang dangkal. Pengukuran dilakukan pada 8 titik, sehingga nilai K yang digunakan adalah rata-rata nilai konduktivitas hidraulik dari kedelapan titik tersebut. Nilai konduktivitas hidraulik kemudian digunakan untuk menentukan nilai Sy berdasarkan pada hasil-hasil penelitian sebelumnya. Perhitungan kuantitas airtanah statis dilakukan dengan persamaan 1.

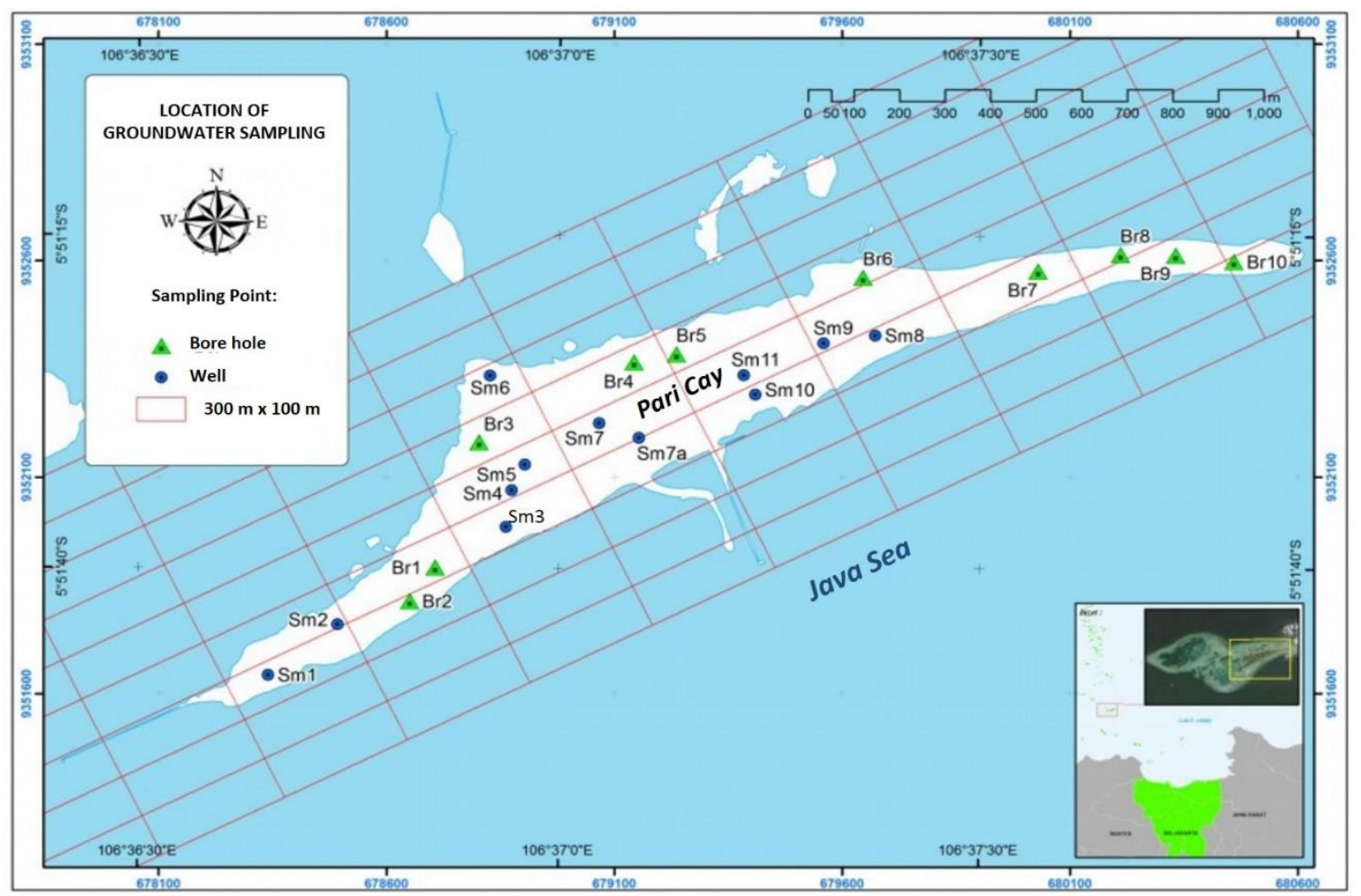

Gambar 1. Lokasi pengambilan sampel airtanah di Pulau Koral Pari.

$\mathbf{V}_{\text {fw }}=\operatorname{Sy} \times V_{\text {aq }}$

\section{Keterangan:}

$\mathrm{V}_{\mathrm{fw}}=$ Volume airtanah tawar yang dapat dimanfaatkan

Sy $=$ Spesific Yield

$\mathrm{V}_{\mathrm{aq}} \quad=$ Volume akuifer dengan airtanah tawar 
Paper ini adalah versi Bahasa Indonesia dari paper kami yang berjudul "Water Resources in Pari Cay, Kepulauan Seribu, Jakarta, Indonesia". Paper ini kami submit ke "The Second International Conference on Environmental Resources Management in Global Region". Konferensi insyaAllah diselenggarakan di Fakultas Geografi UGM tanggal 22 - 23 Oktober 2018.

\section{Results and Discussion}

\subsection{Kondisi Sumberdaya Air Meteorologis di Pulau Koral Pari}

Hasil analisis data menunjukkan bahwa curah hujan rata-rata tahunan di Pulau Koral Pari adalah $1.783 \mathrm{~mm} / \mathrm{tahun}$. Curah hujan ini termasuk rendah, mengingat pulau ini terletak di kawasan tropis. Namun demikian, pulau koral biasanya memang memiliki curah hujan yang rendah karena tidak adanya faktor elevasi yang tidak dapat menghambat gerakan awan, sehingga awan hujan hanya melewati pulau koral ini. Kondisi berbeda terjadi pada pulau gunungapi, di mana elevasinya memungkinkan terjadinya hujan orografis. Kondisi tersebut menyebabkan pulau-pulau gunungapi dan pulau besar dengan elevasi yang tinggi akan memiliki curah hujan yang lebih besar.

Suhu udara di Pulau Koral Pari memiliki fluktuasi harian yang cukup tinggi. Suhu pada siang hari dapat mencapai $32^{\circ} \mathrm{C}$, sedangkan pada malam hari dapat menjadi $22^{\circ} \mathrm{C}$. Rerata suhu harian di Pulau Koral Pari adalah $27^{\circ} \mathrm{C}$, dengan kelembaban udara $80 \%$. Tingginya suhu udara pada siang hari mempengaruhi besarnya evaporasi potensial (Ep) dan evapotranspirasi aktual (Ea) di Pulau Koral Pari. Hasil perhitungan dengan menggunakan metode Thorntwaite-Mather menunjukkan bahwa nilai Ea dan Ep berkisar antara $50 \mathrm{~mm}$ sampai dengan $60 \mathrm{~mm}$.

Hasil perhitungan neraca air meteorologis, nampak bahwa kondisi surplus masih mendominasi, yakni selama 10 bulan. Kondisi defisit terjadi selama dua bulan, yakni pada bulan Juli dan Agustus (Gambar 1). Pada dua bulan ini, berarti ancaman intrusi air laut akan semakin tinggi. Hal ini karena ketersediaan air pada lengas tanah telah habis. Berdasarkan kondisi ini, sebenarnya dari sisi meteorologis sumberdaya air di lokasi kajian berada dalam kondisi yang cukup baik.

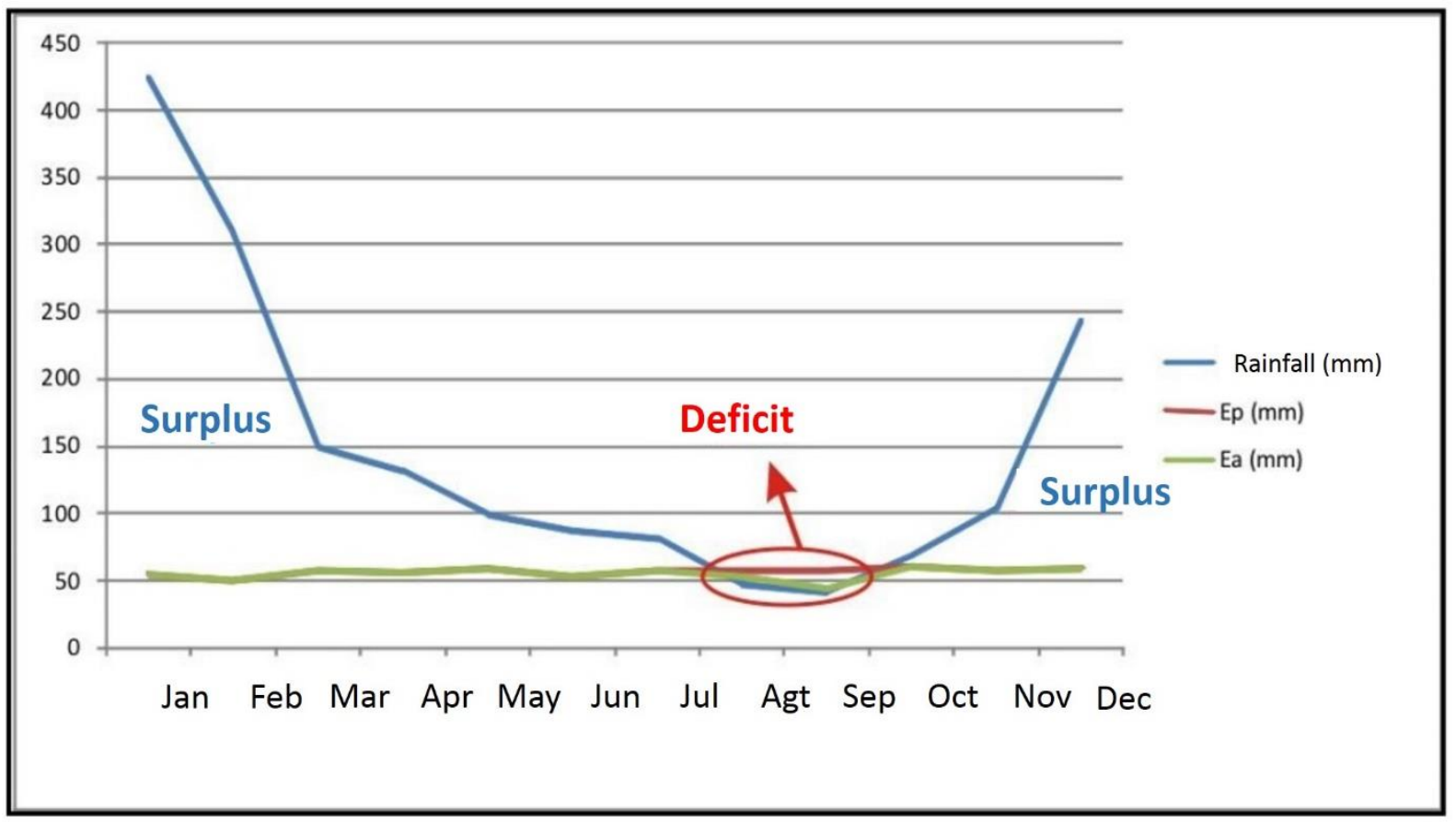

Gambar 2. Neraca Air Meteorologis di Pulau Koral Pari.

\subsection{Kondisi Sumberdaya Airtanah di Pulau Koral Pari}

Hasil analisis laboratorium terhadap sampel airtanah yang diambil dari beberapa sumur dan lubang bor menunjukkan bahwa semua sumber airtanah memiliki kualitas di atas baku mutu air minum. Sampel airtanah yang dianalisis laboratorium hanya beberapa sampel terpilih yang terletak di sekitar permukiman. Hal ini untuk menggambarkan kualitas airtanah yang secara eksisting digunakan oleh masyarakat di Pulau Koral Pari. Parameter yang terlampaui oleh semua sampel airtanah adalah parameter magnesium dan BOD. Pengayaan magnesium merupakan ciri-ciri dari pengaruh intrusi airlaut $[17,18,19]$. Kondisi yang sama ditemukan dalam penelitian sebelumnya yang dilakukan di Pulau Koral Panggang dan Pulau Koral Pramuka. Kedua pulau koral tersebut juga terletak di Gugusan 
Paper ini adalah versi Bahasa Indonesia dari paper kami yang berjudul "Water Resources in Pari Cay, Kepulauan Seribu, Jakarta, Indonesia". Paper ini kami submit ke "The Second International Conference on Environmental Resources Management in Global Region". Konferensi insyaAllah diselenggarakan di Fakultas Geografi UGM tanggal 22 - 23 Oktober 2018.

Kepulauan Seribu, DKI Jakarta. Kondisi tersebut juga didukung dengan terjadinya pengayaan klorida yang terjadi di hampir semua sampel airtanah. Nampak pada Tabel 2 bahwa 4 dari 6 sampel airtanah memiliki kandungan yang melebihi baku mutu air minum.

Tabel 2. Kualitas Airtanah di Pulau Koral Pari.

\begin{tabular}{|c|c|c|c|c|c|c|c|c|c|c|}
\hline \multirow[t]{2}{*}{ No } & \multirow[t]{2}{*}{ Parameter } & \multirow[t]{2}{*}{ Unit } & \multicolumn{6}{|c|}{ Sample Number } & \multirow[t]{2}{*}{ Standard } & \multirow[t]{2}{*}{ Test Method } \\
\hline & & & $\mathrm{Sm} 3$ & $\mathrm{Sm} 4$ & Sm5 & Sm6 & Sm10 & $\mathrm{Br} 2$ & & \\
\hline 1 & $\mathrm{~K}^{+}$ & $\mathrm{mg} / \mathrm{l}$ & 9.0 & 16.0 & 20.0 & 29.0 & 1.0 & 6.0 & 10.0 & APHA 2012 \\
\hline 2 & $\mathrm{Na}^{+}$ & $\mathrm{mg} / \mathrm{l}$ & 45.0 & 472.0 & 493.0 & $1,680.0$ & 69.0 & 378.0 & 200.0 & APHA 2012 \\
\hline 3 & $\mathrm{Ca}^{2+}$ & $\mathrm{mg} / \mathrm{l}$ & 38.2 & 111.4 & 58.1 & 184.67 & 39.8 & 80.0 & 100.0 & $\begin{array}{l}\text { SNI 06- } \\
6989.12- \\
2004\end{array}$ \\
\hline 4 & $\mathrm{Mg}^{2+}$ & $\mathrm{mg} / \mathrm{l}$ & 51.7 & 89.0 & 93.3 & 183.8 & 53.68 & 83.2 & 50.0 & $\begin{array}{l}\text { SNI 06- } \\
6989.12- \\
2004\end{array}$ \\
\hline 5 & $\mathrm{Cl}^{-}$ & $\mathrm{mg} / \mathrm{l}$ & 17.4 & 632.8 & 610.4 & $2,134.1$ & 115.1 & 625.4 & 250.0 & $\begin{array}{l}\text { SNI } \\
6989.19 .200 \\
9\end{array}$ \\
\hline 6 & $\mathrm{HCO}_{3}^{-}$ & $\mathrm{mg} / \mathrm{l}$ & $\begin{array}{l}392 . \\
0\end{array}$ & 491.5 & 367.1 & 398.2 & 304.9 & 454.2 & 500.0 & APHA 2012 \\
\hline 7 & $\mathrm{SO}_{4}^{-}$ & $\mathrm{mg} / \mathrm{l}$ & 6.0 & 40.0 & 63.0 & 272.0 & 7.0 & 55.0 & 250.0 & $\begin{array}{l}\text { SNI } \\
6989.20 .200 \\
9\end{array}$ \\
\hline 8 & $\mathrm{NO}_{2}$ & $\mathrm{mg} / \mathrm{l}$ & 0.20 & 0.04 & 0.04 & 0.11 & 0.05 & 0.14 & 3.0 & $\begin{array}{l}\text { SNI 06- } \\
6989.12- \\
2004\end{array}$ \\
\hline 9 & $\mathrm{NO}_{3}$ & $\mathrm{mg} / \mathrm{l}$ & 0.27 & 0.61 & 28.19 & 5.43 & 0.44 & 2.55 & 50.0 & APHA 2012 \\
\hline 10 & BOD & $\mathrm{mg} / \mathrm{l}$ & 3.0 & 5.4 & 2.8 & 3.0 & 2.4 & 2.7 & 6.0 & $\begin{array}{l}\text { SNI } \\
6989.72 .200 \\
9\end{array}$ \\
\hline 11 & COD & $\mathrm{mg} / \mathrm{l}$ & 19.4 & 24.6 & 12.5 & 15.7 & 10.4 & 15.7 & 10.0 & $\begin{array}{l}\text { SNI } \\
6989.2 .2009\end{array}$ \\
\hline
\end{tabular}

Sumber: Hasil analisis laboratorium.

Keterangan: Kolom berwarna merah berarti parameter melebihi baku mutu

Hasil pemetaan nilai daya hantar listrik menunjukkan bahwa airtanah di Pulau Koral Pari memiliki salinitas yang rendah (fresh water) sampai dengan tinggi (saline). Keberadaan airtanah tawar terletak pada bagian tengah pulau koral (Gambar 3) dan pada penutup lahan berupa semak belukar atau lahan terbuka. Keberadaan airtanah di bagian tengah terjadi karena pada bagian inilah pengaruh intrusi air laut paling kecil. Selain itu, penggunaan lahan berupa semak belukar dan lahan kosong menyebabkan tidak adanya pengambilan airtanah, sehingga pada wilayah ini airtanah tidak/sedikit terpengaruh air laut.

Kondisi sumberdaya airtanah di Pulau Koral Pari lebih baik dibandingkan dengan beberapa pulau koral lain di Gugusan Kepulauan Seribu [11, 20, 21]. Hal ini karena tiga alasan, yaitu (1) luas Pulau Koral Pari yang lebih besar, (2) jumlah dan kepadatan penduduk yang lebih sedikit, dan (3) masih banyaknya penggunaan lahan yang berupa lahan terbuka dan semak belukar. Namun demikian, dengan adanya trend pertambahan penduduk dan pertambahan jumlah wisatawan, kondisi ini dapat saja semakin memburuk jika tidak dikelola dengan sebaik-baiknya. 
Paper ini adalah versi Bahasa Indonesia dari paper kami yang berjudul "Water Resources in Pari Cay, Kepulauan Seribu, Jakarta, Indonesia". Paper ini kami submit ke "The Second International Conference on Environmental Resources Management in Global Region". Konferensi insyaAllah diselenggarakan di Fakultas Geografi UGM tanggal 22 - 23 Oktober 2018.

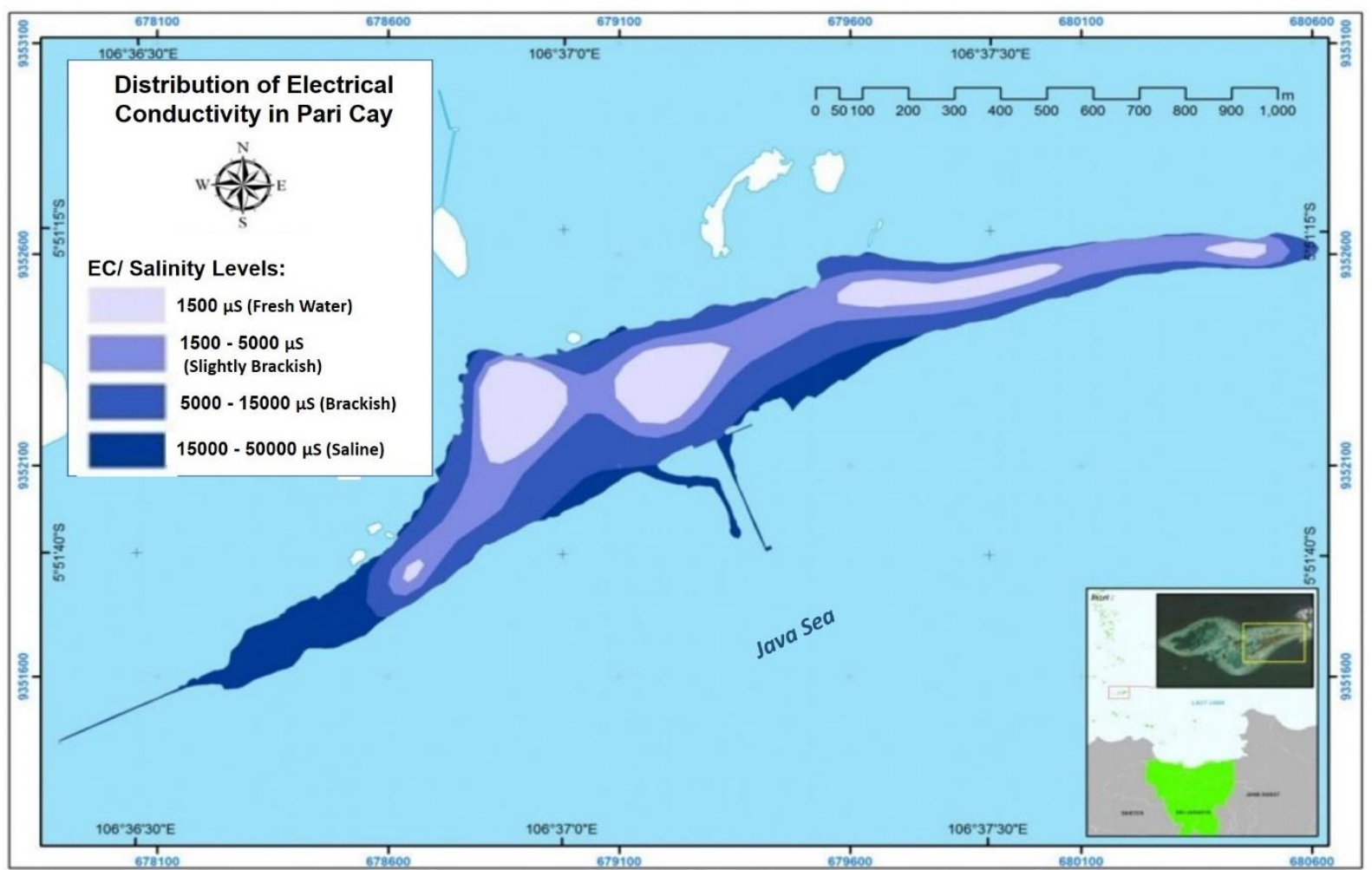

Gambar 3. Distribusi spasial daya hantar listrik dan tingkat salinitas airtanah di Pulau Koral Pari.

Berdasarkan hasil perhitungan yang terlah dilakukan (berdasarkan Gambar 3) diketahui luasan daerah di Pulau koral Pari yang memiliki ketersediaan airtanah tawar sebesar 93.239,13 $\mathrm{m}^{3}$ atau sekitar 9,3 Ha. Berdasarkan perhitungan dengan metode Ghyben-Herzberg, akuifer di Pulau Koral Pari memiliki ketebalan rata-rata 29,2 meter. Nilai pengukuran hydraulic conductivity (K) menunjukkan angka 7,6 m/hari sampai dengan $15,2 \mathrm{~m} /$ hari. Nilai tersebut sama dengan nilai $\mathrm{K}$ untuk material berukuran pasir sedang [14]. Hal ini berarti nilai specific yield (Sy) adalah sebesar 27\% (sesuai dengan nilai Sy untuk material pasir sedang. Dengan demikian, maka potensi air tawar yang terdapat di Pulau Koral Pari kurang lebih sekitar 154.370,43 $\mathrm{m}^{3}$. Potensi airtanah di Pulau koral Pari ini merupakan suatu potensi airtanah secara kasar dengan asumsi setiap daerah di Pulau koral Pari memiliki ketebalan dan respon akuifer yang sama.

Potensi airtanah tawar yang terdapat di Pulau Koral Pari paling banyak di temukan pada tengah pulau. Kondisi ini merupakan kondisi yang umum terjadi pada pulau koral sangat kecil [22]. Bentuk lensa air tawar akan simetri mengikuti bentuk topografi permukaan dan menebal di bagian tengah pulau apabila kondisi material dan struktur geologinya homogen.

Airtanah Pulau koral Pari pada umumnya termasuk airtanah dangkal karena memiliki kedalaman maksimum 1,4 meter. Rata-rata ketinggian muka airtanah (TMA) tidak lebih tinggi dari 0,9 m. Sisi selatan dan sisi utara Pulau koral Pari memiliki kedalaman airtanah yang cukup berbeda. Pada sisi selatan Pulau koral Pari kedalaman muka airtanahnya lebih dangkal dibandingkan dengan sisi utara. Ini dikarenakan pada sisi selatan proses erosi oleh air laut lebih intensif dibandingkan dengan pada sisi utara. Pada sisi utara proses yang lebih dominan adalah pengendapan, sehingga memiliki ketinggian daratan semakin besar dan kedalaman airtanahpun juga semakin besar. Kondisi material yang memiliki konduktivitas hidraulik yang tinggi serta muka airtanah yang sangat dangkal menyebabkan airtanah di Pulau Koral Pari memiliki kerentanan pencemaran yang tinggi.

Berdasarkan wawancara dan pengamatan di lapangan, kondisi ketinggian muka airtanah yang terdapat di Pulau koral Pari juga terpengaruh oleh fluktuasi muka air laut. Pengaruh fluktuasi air laut ini terlihat dari perubahan muka airtanah yang terdapat di pulau koral tersebut. Apabila airlaut pasang, maka muka airtanah pada sumur yang berada di dekat laut akan naik. Begitu pula sebaliknya apabila 
Paper ini adalah versi Bahasa Indonesia dari paper kami yang berjudul "Water Resources in Pari Cay, Kepulauan Seribu, Jakarta, Indonesia". Paper ini kami submit ke "The Second International Conference on Environmental Resources Management in Global Region". Konferensi insyaAllah diselenggarakan di Fakultas Geografi UGM tanggal 22 - 23 Oktober 2018.

air laut surut, maka muka airtanah pada sumur yang berada dekat dengan pantai akan mengalami penurunan.

Potensi airtanah yang terdapat di Pulau Koral Pari dapat berkurang dengan sangat cepat diakibatkan perubahan - perubahan kondisi yang terdapat di pulau tersebut. Ketebalan akuifer yang terdapat di Pulau Koral Pari tidak terlalu tebal menjadikan simpanan airtanah yang terdapat di pulau tersebut sangat rentan terhadap penurunan kualitas dan kuantitasnya. Dari total potensi airtanah yang terdapat di Pulau koral Pari, tidak semuanya dapat langsung diambil dan dimanfaatkan. Pengambilan yang berlebihan akan dapat mempercepat penurunan kuantitas airtanah karena akan mempercepat intrusi air laut $[23,24,25]$.

\section{Conclusion}

Pulau Koral Pari memiliki curah hujan yang rendah karena elevasi yang rendah dan bermorfologi datar. Namun demikian, hasil analisis neraca air meteorologis menunjukkan kondisi deficit hanya terjadi pada Bulan Juli dan Agustus. Selain itu, kondisi airtanah di Pulau Koral Pari cukup baik dibandingkan dengan pulau-pulau koral lain di Gugusan Kepulauan Seribu. Hal ini karena luas Pulau Koral Pari merupakan yang paling luas, masih banyaknya lahan non-terbangun (lahan terbuka dan semak belukar), serta jumlah dan kepadatan penduduk yang relative lebih rendah. Meskipun demikian, hasil analisis kualitas air menunjukkan adanya pengaruh intrusi air laut yang dicirikan oleh adanya pengayaan magnesium dan klorida dalam airtanah, serta tingginya nilai daya hantar listrik yang menyebabkan variasi tingkat salinitas sampai dengan kategori saline.

\section{References}

[1] Anggraini D F 2013 Analisis Daya Dukung Lingkungan untuk Kawasan Ekowisata Pulau Pramuka, Kepulauan Seribu, Daerah Khusus Ibukota Jakarta M.Sc. Thesis (Yogyakarta: Master Program on Planning and Management of Coastal Area and Watershed, Faculty of Geography, Universitas Gadjah Mada)

[2] Cahyadi A and Tivianton, T A 2013 Persepsi Masyarakat Terhadap Pemanenan Air Hujan dan Dampaknya Terhadap Ketahanan Sumberdaya Air di Pulau Pramuka, Kepulauan Seribu, DKI Jakarta. in Pengelolaan Lingkungan Zamrud Khatulistiwa, ed M A Marfai and M Widyastuti (Yogyakarta: Buku Pintal)

[3] Cahyadi A 2015 Analisis Potensi Sumberdaya Air Pulau Koral Sangat Kecil (Studi Kasus di Pulau Koral Pramuka, Kabupaten Kepulauan Seribu, DKI Jakarta) M.Sc. Thesis (Yogyakarta: Master Program on Planning and Management of Coastal Area and Watershed, Faculty of Geography, Universitas Gadjah Mada)

[4] Falkland C A 1991 Hydrology and Water Resources of Small Island: A Practical Guide (Paris: Unesco)

[5] Falkland C A 1993 Hydrology and Water Management in Small Tropical Island Proceeding of The Yokohama Symposium on Hydrology on Warm Humid Region (Yokohama, Japan, 13-15 July 1993)

[6] Cahyadi A, Hidayat W and Wulandari 2013. Adaptasi Masyarakat Terhadap Keterbatasan Sumberdaya Air di Pulau Pramuka, Kepulauan Seribu, DKI Jakarta Jurnal Penelitian Kesejahteraan Sosial 12(2) 207 - 213

[7] Arenas A A D and Huertas J F 1986 Hydrology and Water Balance of Small Island: A Review of Existing Knowledge (Paris: UNESCO)

[8] Cahyadi A 2012 Permasalahan Sumberdaya Air di Pulau Karang Sangat Kecil (Studi Kasus di Pulau Pramuka, Kabupaten Kepulauan Seribu, DKI Jakarta) Proceeding of the National Natural Resources and Environmental Management (Semarang: Environmental Science Study Program, Universitas Diponegoro)

[9] Cahyadi A, Marfai M A, Tivianton T A, Wulandari and Hidayat W 2015 Menyelamatkan Masa Depan Pulau-Pulau Kecil Indonesia Proceeding of the National Geography Meeting 2013 (Yogyakarta: Faculty of Geography, Universitas Gadjah Mada)

[10] Cahyadi A, Agniy R F and Suhana S N 2015 Karakterisasi Hidrogeokimia Airtanah untuk Analisis Genesis Airtanah di Pulau Koral Sangat Kecil Proceeding of the First National Seminar 
Paper ini adalah versi Bahasa Indonesia dari paper kami yang berjudul "Water Resources in Pari Cay, Kepulauan Seribu, Jakarta, Indonesia". Paper ini kami submit ke "The Second International Conference on Environmental Resources Management in Global Region". Konferensi insyaAllah diselenggarakan di Fakultas Geografi UGM tanggal 22 - 23 Oktober 2018.

rosiding on Coastal Area and Watershed Management (Yogyakarta: Master Program on Planning and Management of Coastal Area and Watershed, Faculty of Geography, Universitas Gadjah Mada)

[11] Cahyadi A, Adji T N and Marfai M A 2015 Analisis Evolusi Hidrogeokimia Airtanah di Pulau Koral Pramuka, Kepulauan Seribu Proceeding of National Seminar on Geography (Surakarta: Universitas Muhammadiyah Surakarta)

[12] Cahyadi A, Adji T N and Marfai M A 2016 Uji Akurasi Aplikasi Electromagnetic Very Low Frequency (EM VLF) untuk Analisis Potensi Airtanah di Pulau Sangat Kecil Proceeding of the Second National Seminar rosiding on Coastal Area and Watershed Management (Yogyakarta: Master Program on Planning and Management of Coastal Area and Watershed, Faculty of Geography, Universitas Gadjah Mada)

[13] Wijonarko S 2011 Meteorologi Pulau Pramuka, Kepulauan Seribu, in Rona Lingkungan Pulau Pramuka, eds O S R Ongkosongo, S Wijonarko, and Afadlal (Jakarta: Lembaga Ilmu Pengetahuan Indonesia (LIPI), Pusat Penelitian Oseanografi, Balai Dinamika Laut, Kolompok Penelitian Geologi Laut)

[14] Todd D K and Mays L W 2004 Groundwater Hydrology, Thrid Edition (New York: John Wiley \& Sons)

[15] Gilli E, Mangan C and Mudry J 2012 Hydrogeology: Objectives, Methods, Applications (Boca Raton: CRC Press)

[16] Custodio E 2005 Coastal Aquifer as Important Natural Hydrogeological Structures. in Groundwater and Human Development, ed E M Bocanegra, M A Hernandez and E Usunoff (Leiden: A.A. Balkema Publisher)

[17] Šráček O and Zeman J 2004 Introduction to Environmental Hydrogeochemistry (Brno: Faculty of Science, Masaryk University)

[18] Aris A Z, Abdullah M H, Ahmed A and Woong K K 2007 Controlling Factors of Groundwater Hydrochemistry in A Small Island's Aquifer International Journal of Environmental Science and Technology 4 (4) 441-450

[19] Aris A Z, Praveena S M and Isa N M 2013 Groundwater Composition and Geochemical Controls in Small Tropical Island of Malaysia: A Comparative Study, in Groundwater in The Coastal Zones of Asia-Pacific, ed C Wetzelhuetter (Dordrecht: Springer)

[20] Cahyadi A, Marfai M A, Tivianton T A, Wulandari and Hidayat W 2013 Analisis Distribusi Spasial Salinitas Airtanah di Pulau Pramuka, Kepulauan Seribu, DKI Jakarta Proceeding on National on Geospatial Information Utilization (Surakarta: Universitas Muhammadiyah Surakarta)

[21] Cahyadi A and Hidayat W 2017 Analisis Karakteristik Hidrogeokimia Airtanah di Pulau Koral Panggang, Kepulauan Seribu, DKI Jakarta Jurnal Geografi 9(2) 99-108

[22] Arsadi E M and Sumawija N 1995 Air Tanah Pulau Kecil dan Sangat Kecil Proceeding of National Symposium on Water Resources Management in Indonesia (Bandung : Institut Teknologi Bandung)

[23] Sen Z 2015 Practical and Applied Hydrogeology (Waltham, UK: Elsevier)

[24] Karamouz M, Ahmadi A and Akhbari M 2011 Groundwater Hydrology: Engineering, Planning and Management (Boca Raton: CRC Press)

[25] WWAP (World Water Assessment Programme) 2009 The United Nations World Water Development Report 3: Water in a Changing World (Paris: UNESCO Publishing) 